\title{
Implementation of Rehabilitation for Drug Addicts Based on Law Number 35 of 2009 on Narcotics in Jakarta
}

\author{
Ricky F.M.A Purwanto ${ }^{1}$, Faisal Santiago ${ }^{2}$, Alfon Octavianus Sitepu ${ }^{3}$ \\ \{Rickypurwanto1974@gmail.com¹, Faisalsantiago@yahoo.com² ${ }^{2}$ advokatalfonsitepu@gmail.com ${ }^{3}$ \} \\ Universitas Borobudur, Jakarta, Indonesia ${ }^{1,2,3}$
}

\begin{abstract}
Indonesia is a state subject to law which is regulated by an evenhanded law. This obligation is contained in Article 1 entry (3) of the 1945 Constitution of the Republic of Indonesia which communicates that Indonesia is a consecrated state. Some fundamental principles of the state of law is the presence of an independent and reasonable lawful leader and the incomparable nature of law that contains the standard of consistency under the careful focus of the law and the rule of legitimateness (reasonable treatment of law). According to the standard of a rule of peace and law, Based On Law Number 35 Of 2009 On Narcotics confirms that the lawful power is an independent capacity to supervise value to maintain law and value. This game plan focuses on that judges are not the mouthpiece of the law; they have the obligation to give a sensation of value to the neighborhood. Judges should not be trapped in a vacuum accepting there is no law, the law is vague or doesn't facilitate with the value of value. This survey hopes to assess how judges make or track down their legitimate decisions on criminal cases of sedatives abuse.
\end{abstract}

Keywords: Drug; Narcotics; Law Number 35 Of 2009; Rehabilitation

\section{Introduction}

In line with the development of Indonesian people, especially Jakarta, which is so central, it is directly proportional to the mindset and behavior of the people of the capital city of Jakarta. The people need laws and regulations as a reference or guideline to control the development of society in a positive direction, in this case the law is very important.[1] In everyday reality, although a legal regulation has been made to regulate the people of the capital city of Jakarta, there are some people or groups of people in Jakarta who do not obey the law.

The development of narcotics crime in Jakarta is increasingly alarming in life and in society, it is evident that the rate of development of narcotics crime in Jakarta is increasing from year to year growing very rapidly even though there is Law No. 35 of 2009 which regulates narcotics but victims are increasingly many and regardless of age and social status, more and more are trapped in a vicious circle caused by the narcotics, as well as those who 
have been addicted to narcotics and ironically the victims are teenagers and young people who are the nation's next generation.[2]

Narcotics abuse is a type of crime that has potential to occur anywhere, both in Jakarta and in other areas. The occurrence of problem issue, raises the question of who has the authority to deal with the problem.[3] There are several provisions governing the rehabilitation of narcotics addicts in Law narcotics, there are several articles that are still disputed. If it is associated with rehabilitation opportunities for the drug addicts. There is still a threat of imprisonment for any narcotics abuse, namely Article 127 paragraph (1) which states that any abuse of:

1. Narcotics group 1 (one) for oneself shall be punished with a maximum imprisonment of 4 (four) years.

2. Narcotics class II (two) for oneself shall be punished with a maximum imprisonment of 2 (two) years.

3. Narcotics class III (three) for oneself shall be punished with imprisonment for a maximum of 1 (one) year.

Furthermore, Article 127 paragraph (3) states that narcotics abuse is obligatory to go through clinical restoration and social recovery, the definition can be demonstrated will be demonstrated in the arrangements of the article. This implies that an opiates fiend should be demonstrated or is shown to be a survivor of opiates maltreatment through a cycle known as a coordinated appraisal.[4]

When viewed from the existing reality that since Law of narcotics was enacted, but until now the implementation of rehabilitation is still far from what is expected where the implementation of rehabilitation itself does not serve optimally, due to various shortcomings such as labor facilities, incomplete and the facilities on medical equipment are also not complete.[5] Whereas discrimination against narcotics addicts by putting them in prison will be very ineffective, but if they are included in rehabilitation and monitored until they are healthy, it is certain that the number of drug addicts can be suppressed.

Supporting factors in order to achieve: rehabilitation on the drug addicts.

1. Legislative factor (legal substance) in the practice the implementers in the field, frequently having a conflict between legal certainty and justice.

2. Law enforcement factor. One of the keys to success in achieving the implementation of rehabilitation for narcotics use is the mentality or personality of the law enforcers themselves.

3. Supporting facilities and infrastructure factor. Supporting facilities and facilities include doctors, medical personnel, adequate equipment, very good and proper rehabilitation facilities.

4. Community/environmental factor. The community has a strong influence on the implementation of narcotics rehabilitation. Community or the environment is the most important part.

\section{Methods}

The method of research used is juridical normative with regulatory approach which is conducted by seeing every regulation and constitution related to the law issue at hand. Beside juridical normative, research will also be done by using juridical empiric through researching the principles of law.[6] Based on the type of research used, the source of the law materials is secondary data gained from literature resources which covers the primary, secondary and 
tertiary law. The technique for gathering law material used is library research to obtain theoretical concept, doctrines, opinions or conceptual thoughts in relevance with the research in form of constitutional regulations, books, written literature and other works.[7]

\section{Discussion}

Rehabilitation of narcotics addicts requires a long time, adequate facilities and drugs as well as competent professional personnel and considerable costs, this rehabilitation involves various professions and expertise, namely doctors/nurses, psychology, religious advisors/supervising officers and supervisors of social rehabilitation homes, psychiatrists, and Social workers who have received special training to serve narcotics addicts.[8] Effectiveness Of The Rehabilitation Program And Process For Narcotic Addicts Is Determined By Some Of Factors, They Are:

a. Strong desire and cooperation from the drug addict.

b. Professionalism, competence and commitment from the implementers

c. Good referral system among the institutions

d. Adequate infrastructure and facilities

e. Attention and order from parents and family as well as adequate financial support.

Law No. 35 of 2009 concerning narcotics requires narcotics addicts to participate in a rehabilitation program in several forms and methods in the implementation of rehabilitation for narcotics addicts.[9] Such as medical rehabilitation, but in its implementation, medical rehabilitation methods are combined into one so that it becomes a four-stage process of narcotics addicts, namely:

a. Health examination stage at this stage a doctor and a nurse have a very important role to check early, whether the health condition of the patient/ prisoner is good or not, the history of the disease he has suffered and then all data about physical characteristics.

b. Detoxification phase of narcotic-free therapy and physical therapy aimed at reducing and eliminating toxins from the body, reducing the effects of withdrawal from narcotics and treating mental complications of the patient.

c. Stabilization stage, mental and emotional atmosphere of the patient, so that $t$ mental disorder that causes the act of narcotics abuse may be overcome at this stage, carried out by involving several skills such as supervisors and coaches and psychologists, namely through social work methods.

d. Social guidance / individual therapy. Social guidance in the form of individual therapy is conducted to reveal or expose the problems.

In view of the Law of the Republic of Indonesia Number 35 of 2009 concerning Narcotics, the meaning of opiates is a substance or medication got from plants or non-plants, both manufactured and semi-engineered which might cause an abatement or change in awareness, loss of faculties, decrease and to dispense with torment and may cause conditions which are partitioned into bunches as joined in Law Number 35 of 2009. Classification of narcotics based on Law No. 35 of 25 of 2009 :

a. Group 1 is opiates that must be utilized for logical purposes and for restorative purposes and have an extremely high potential to cause reliance, (for example, heroin/putaw, cocaine, cannabis)

b. Group II is opiates that are effectual, treatment is utilized if all else fails and can be utilized in treatment to foster science and has a high potential to cause reliance (morphine peditine). 
In order to achieve the implementation of rehabilitation for narcotics addicts in Jakarta, the Jakarta City Narcotics Agency should improve and maximize performance in order to reduce narcotics abuse and eradicate narcotics, DKI Jakarta government must add rehabilitation centers in the city of Jakarta, considering that there have been many cases of drug abuse in the city of Jakarta. Even though there were already drug addiction hospitals in Jakarta but facilities are inadequate and the space is very few, the government should complete facilities such as sports facilities, play facilities and entertainment facilities as well as increase the lack of medical workers in order to realize the goals of rehabilitation and for the recovery of victims of drug abuse in the city of Jakarta.

Considering Article 4 of Law Number 35 Year 2009 concerning Narcotics, this Law means to (1) guarantee the openness of Narcotics to help prosperity organizations or possibly the improvement of science and development; (2) hinder, safeguard and save the Indonesian country from abuse of Narcotics; (3) demolish the unlawful managing of Narcotics and Narcotics recursors; and (4) guarantee the strategy of clinical and social reclamation attempts for Narcotics lowlifes and addicts.

The significance of sedatives miscreant is contained in Article 1 point 15 of Law Number 35 of 2009 concerning Narcotics. According to this article, a lowlife is a person who uses Narcotics without opportunities or unlawful. Rules for criminal endorsements for self abuse are overseen in Article 127 of Law Number 35 of 2009 concerning Narcotics, explicitly, every lowlife of (1) sedatives class I for himself will be sentenced to confinement of a restriction of 4 (four) quite a while; (2) Narcotics class II for themselves will be rebuked with confinement of 2 (two) quite a while; and (3) narcotics characterization III for themselves will be repelled with confinement of 1 (one) year. Chosen in picking examples of sedatives scoundrels for themselves as referred to above are expected to zero in on the courses of action implied in Article 54, Article 55, and Article 103 of Law Number 35 of 2009 concerning Narcotics. On the off chance that the scoundrel can be exhibited or demonstrated to be a loss of sedatives abuse, the miscreant is obliged to go through clinical recuperation and social rebuilding.

The utilization of criminal plans against lowlifes cause issues eventually. The criminal plans in Law Number 35 of 2009 concerning Narcotics are not satisfactory to give value to sedatives lowlifes. Lowlifes of narcotics for their own usage can be charged using the article that should be applied to people related with the unlawful managing of sedatives. The criminal plans can be seen from Article 111 Paragraph (1), Article 112 Paragraph (2), and Article 114 Paragraph (1) of Law Number 35 Year 2009 concerning Narcotics.

\section{Conclusion}

The aftereffects of the examination referenced that relational correspondence and gathering correspondence is done in the exercises of morning gatherings, night gatherings, and conflicts. Social restoration did by advocates at home medication treatment utilizes relational correspondence and gathering correspondence. Relational correspondence is utilized in the underlying meeting, day by day collaboration and advising stages. Basically, the rule of restoration utilized is gathering or local area treatment with the customer at the middle (customer focused treatment). This people group treatment depends on the guideline of open correspondence and electing to help one another (common assistance). An organized climate is worked to cultivate significance by living respectively with others. This can't be settled alone yet with the assistance of others, be it through good examples or social capacities. Similarly, when a customer recuperated, he kept on assuming a part in the NA (Narcotics 
Anonymous) meeting, helping other people (administration) and aiding explicitly by being a supporter for mending different addicts. The rule of correspondence that happens in the helpful cycle is open, non-critical, deliberate, evaluative, system based and organized. The NA

rule is profound despite the fact that it isn't associated with a specific religion. The advocate is a tenable communicator with his capability and experience.

\section{References}

[1] P. Soerjowinoto, T. M. Wibowo, and S. H. Baskoro, "PELAKSANANAN REHABILITASI TERHADAP PECANDU NARKOBA SECARA SUKARELA DAN MELALUI PROSES PENEGAKAAN HUKUM. (STUDI KASUS DI BBNP JATENG)," Huk. Dan Din. Masy., vol. 17, no. 1, 2019, doi: 10.36356/hdm.v17i1.1281.

[2] R. Haryadi, "Prospek Konseling Komunitas bagi Individu Eks-Pecandu Narkoba (Studi Pada Lembaga Pasca-Rehabilitasi Narkoba Di Kota Semarang)," KONSELI J. Bimbing. dan Konseling, vol. 5, no. 1, 2018, doi: 10.24042/kons.v5i1.2562.

[3] P. De Silva and P. Fonseka, "Drug addicts and their behaviour related to drug addiction among the institutionalized addicts of the Galle District," Gall. Med. J., vol. 13, no. 1, 2009, doi: 10.4038/gmj.v13i1.886.

[4] A. P. B. Pratama, "IMPLEMENTASI PUTUSAN REHABILITASI BAGI PENYALAHGUNA NARKOTIKA DI PENGADILAN NEGERI SURABAYA,” $J$. Huk. Magnum Opus, vol. 3, no. 2, 2020, doi: 10.30996/jhmo.v3i2.3462.

[5] "Dynamics of Psychological Characteristics of Drug Addicts in the Period of Rehabilitation For Up to One Year and From One to Five Years," Psychol. Couns. Psychother., no. 11, 2019, doi: 10.26565/2410-1249-2019-11-04.

[6] D. L. Sonata, "METODE PENELITIAN HUKUM NORMATIF DAN EMPIRIS: KARAKTERISTIK KHAS DARI METODE MENELITI HUKUM," FIAT JUSTISIAJurnal Ilmu Huk., 2015, doi: 10.25041/fiatjustisia.v8no1.283.

[7] M. Abdul Kadir, "Hukum Dan Penelitian Hukum.," Bandung PT. Citra Aditya Bakti., 2015.

[8] Y. Saefudin, A. Raharjo, and B. Budiono, "URGENCY OF INTEGRATED ASSESSMENT ON DRUGS CRIME (A Study in Purbalingga Regency),” J. Din. Huk., vol. 17, no. 1, 2017, doi: 10.20884/1.jdh.2017.17.1.818.

[9] M. H. haniyah, "Juridical Review of Decriminalization on Efforts to Cut Drugs Users' Addiction In Indonesia," YURIDIKSI, vol. 11, no. Vol 11 No 1 (2018): March 2018, 2018. 